\title{
Time MANAGEMENT IN THE PROFESSION OF NURSE MANAGER - A CASE STUDY
}

\author{
Anna Piskorz ${ }^{1, A, B, C, D}$, Beata Ruchała ${ }^{2, A, B}$, Anna Leonarda Nowacka ${ }^{1, E, F}$, Renata Wolfshaut-Wolak ${ }^{3, E, F}$
}

\begin{abstract}
'Department of Nursing Management and Epidemiological Nursing, Faculty of Health Sciences, Jagiellonian University Medical College, Krakow, Poland

${ }^{2}$ First Cycle degree nursing student, Institute of Nursing and Midwifery, Faculty of Health Sciences, Jagiellonian University Medical College, Krakow, Poland

${ }^{3}$ Department of Epidemiology and Population Research, Faculty of Health Sciences, Jagiellonian University Medical College Krakow, Poland
\end{abstract}

\section{Authors' contribution:}

A. Study design/planning • B. Data collection/entry • C. Data analysis/statistics $\bullet$ D. Data interpretation $\bullet$ E. Preparation of manuscript $\bullet$ F. Literature analysis/search $\bullet$ G. Funds collection

\author{
Address for correspondence: \\ Anna Piskorz \\ Department of Nursing Management \\ and Epidemiological Nursing \\ Faculty of Health Sciences \\ Jagiellonian University Medical College \\ 25 Kopernika St. \\ 31-501 Krakow, Poland \\ e-mail: anna.piskorz@uj.edu.pl
}

SUBMITTED: 05.12 .2019

ACCEPTED: 02.01.2020

DOI: https://doi.org/10.5114/ppiel.2019.92542

\begin{abstract}
Introduction: Time management is an essential component of the management process, which can not only affect employees' efficiency as far as their reaching professional and personal goals is concerned but also increase the performance of their organisation.

Aim of the study: The study was aimed at demonstrating the importance of the manager's time management and presenting the effects of time management on the example of a nurse manager's work.

Material and methods: The research was based on a case study. The object of the study was a ward nurse working in the intensive care unit of one of district hospitals in Małopolska region. An interview technique was applied in the study. The authors made use of their own questionnaire consisting of questions about socio-demographic data, employment history, and opinions about time management as well as a standardised SWOT analysis questionnaire, Time Consumers questionnaire, and a questionnaire entitled 'Self-assessment of the use of working time - identifying time thieves'.

Results: The subject of the study was a 44-year-old woman working as a ward nurse in the anaesthesiology and intensive care unit. According to this nurse manager, the tasks that took up most of her time during her shifts included: supervising how the staff carried out their tasks, managing the team, and planning and carrying out nursing tasks on time. Unexpected visitors turned out to be the most serious time thief. Self-assessment of time management showed that the respondent was able to manage her working time in a responsible way (score of 66). Conclusions: Time management is an essential element of nurse managers' work because it allows them to effectively make use of their working time. Consistency in time management is followed by an improvement in understanding, mastering, and controlling one's tasks; it also reduces the level of stress and haste, and has a positive influence on one's outlook on life.
\end{abstract}

Key words: time, time management, nurse manager, case study.

\section{INTRODUCTION}

Time belongs to limited resources. It is impossible to stop or acquire it in any way. The only solution is to attempt to make use of the time you have as efficiently as possible. The advantages of applying efficient methods of organising your working time result in opportunities to achieve your goals with less effort because of better organisation of work. This is followed by better results at work, and higher motivation and satisfaction from performed functions. Another important advantage is also the fact that such an attitude leads to a reduction in the number of mistakes [1]. The term "time-based management"
(TBM) first appeared in publications in the 1950s, and it became a separate branch of science focused on task organisation and based on regularity and rational planning of activities, which help achieve the goal [2]. In scientific publications there are numerous definitions of time management. Time management, according to Seiwert, is a methodical process based on priorities and taking into account essential needs of the institution in question. Its main aim is proper allocation and distribution of time. Time management can be discussed on a macroeconomic level (e.g. time of waiting for medical services) or on a microeconomic level within services offered by doctors, nurses, hospitals, or basic health care facilities 
as well as on particular positions including a doctor, nurse, head of hospital ward, or ward nurse [3]. In his analyses connected with time management Seiwert points out so-called 'time consumers'. They include numerous factors, for example, unspecified goals, attempted multitasking, untidy documents and schedules, too little delegating, lack of self-discipline, giving in to external pressure, or poor communication in the organisation [4].

When raising the issue of time management, Druker sometimes defines it as a three-step process, which consists of recording how working time is used, time management, and time consolidation. According to this author, the factor that has the biggest influence on efficiency and results of work is the difference between used and wasted time. Druker believes that the main reason for wasting time is poor communication in the organisation [5].

Forsyth, in turn, introduced four categories to the time management process: planning, implementing, monitoring, and controlling how the tasks are performed as well as proper communication and contact with others as far as implementing tasks is concerned. According to this author better time management may change work performance and efficiency, decrease time pressure, and enhance chances for professional success [6].

Chronobiology is a science that examines cyclic phenomena in living organisms. Its name comes from the Greek words chronos (time), bios (life), and logos (science) [7]. The basic notion connected with time management is the structure of biological time understood as a sequence of predictable biological changes resulting from, for example, growth, development, or aging. This new branch of science might be helpful while organising working time on particular positions based on the analysis of employees' biological rhythms [8].

In the group of numerous time rhythms identified by researchers, circadian rhythm seems to be the most important one as far as time management is concerned because it has a direct impact on performing professional duties [7, 9]. Thorough knowledge of this rhythm allows the creation the most rational plan based on the actual capabilities of the human organism. Circadian rhythm depends on well-known fluctuation of body temperature, heart rate rhythm, concentration of hormones and other substances in blood, blood pressure, and other physiological parameters. This rhythm is also an ecological rhythm because it is based on numerous environmental factors depending on the revolution and rotation of the Earth. It is connected with the changes in insolation and temperature, which are reflected by changes in the stages of biological cycles [8]. A sinusoidal rhythm of human body temperature indicates that the maxi- mum values are observed in the afternoon and minimum ones at night. Even greater fluctuations were observed in the functional rhythm of the circulatory system measured by means of intra-arterial catheter. An analysis shows that the highest values were obtained between 11 a.m. and 12 a.m. and the lowest ones between 5 p.m. and 7 p.m. The lowest blood pressure was observed before noon and about 2 a.m. [9]. The curve of working capability shows two peaks of the highest activity in employees: the morning peak between 8 a.m. and 11 a.m. and the afternoon peak between 2 p.m. and 4 p.m. In the evening a significant decrease in activity is observed, which is reflected by the curve and indicates lower working capabilities. The awareness of the cyclic character of daily rhythms makes it possible for employees to avoid neurasthenic symptoms, which mean nervousness connected with their coping with work [10].

Psychological functions are also characterised by daily fluctuations. Research taking into account psychological functions connected with eye-ear coordination, simple reaction time, and mental capacity show a constant level of psychological activity between 12 a.m. and 9 p.m. In turn, the lowest values of psychological activity are observed between 3 a.m. and 6 a.m. [11]. The influence of personal characteristics has not been confirmed by scientific research. However, it must be pointed out that the results are not fully clear-cut because of the incidence of masking daily rhythms. Daily rhythms can be masked by personal or temperamental factors. There are two basic models of daily rhythms. In the case of 'early birds' the highest body temperature is observed between 12 a.m. and 2 p.m. and the lowest temperature just after midnight, which means that these people tend to be most active before noon and their functioning is significantly lowered in the evening. On the other hand, 'night owls' show the peak of their activity between 4 p.m. and 6 p.m., which is reflected by an increase in their body temperature at this time [9]. Fatigue is a natural phenomenon protecting the organism from overburdening and consists of a temporary decrease in working capacity. There are two types of fatigue: psychological and physical. As far as its intensity is concerned, fatigue can be subacute, acute, and chronic [12]. Fatigue can have two types of symptoms: subjective and objective. The objective fatigue symptoms include a considerable decrease in efficiency and an increase in the number of mistakes made by an employee $[12,13]$.

In order to prevent employees from overburdening it is essential to follow the rules of organisation of their working time. The rules that should be applied in this case specify that the total time of all breaks should be equal to or above $15 \%$ of the total working time, and in the case of hard work the break 
time should range between 20 and $30 \%$ of the total working time. If there is only one break, it should take place between $1 / 3$ and $1 / 2$ of the total working time, and if there can be two breaks, the optimal solution is to make them divide the working time into three equal parts. In this case the length of the second one should exceed the length of the first one. The final general rule says that it is beneficial to apply frequent short breaks, bearing in mind that the relaxing effect is strongest in its initial stage [14].

Modern time management is different from the classic model. It is true also about nurse manager's time management. According to Drucker, the characteristics of management include the following ideas:

1. Management refers mainly to people.

2. Management must be deeply rooted in culture.

3. In management it is vital to establish simple and explicit goals for every activity or task.

4. Management should lead to the situation in which an organisation is capable of developing new skills and retains its ability to learn.

5. Management requires communication.

6. Management requires a complex rating system.

7. Management must be client-oriented [5].

Since early 1960s researchers working on manager's work methodology have been convinced about the validity of applying basic organisational methods, which led to professional success. Steward conducted a study on managers' behaviour, which led to the conclusion that time management was influenced by an opportunity to make a choice and limitations and requirements of managerial jobs [15]. The management process can be divided into five stages:

1. Establishing goals, very often based on personal goals, especially regarding the need to limit the amount of work taken home so as to have more time to pursue one's hobbies.

2. Formulating a plan and specifying actions in case of various circumstances.

3. Deciding how the task will be done.

4. Task organisation and completion.

5. Control and possible adjustments [16].

The first step towards time management consists of formulating a goal. This stage increases motivation and eliminates weak points. It also sets deadlines and determines next steps. The second stage, planning, involves all kinds of plans for particular years, months, and weeks, time management techniques, and the ALPEN method. The basic rule determining time management is the $60: 40$ rule, according to which $60 \%$ of time should be devoted to planned activities and $40 \%$ to those that appear unexpectedly. On the other hand, the ALPEN method focuses on organising activities and tasks, estimating their length, and establishing priorities. ALPEN is an acronym formed by German words Aufgaben - making a to-do list for each day, Länge schätzen - estimating the length of these activities and summing up the time, Pufferzeiten einplanen - keeping a buffer for spontaneous activities, which should be a time margin of $40 \%$ of all working time, Entscheidungen treffen - establishing priorities and delegating tasks following the Eisenchower method or ABC analysis, and Nachkontrolle - the final step involving the control over completing the tasks $[4,17,18]$.

Following these rules is essential to be effective and successful in reaching the goals and to divide time in a proper way. The third stage involves making decisions. At this stage the PARETO principle, ABC method, Eisenhower matrix, and delegating tasks to subordinates seem particularly useful. According to P. F. Drucker, delegating work should be preceded by the question of whether it can be done equally well or even better by somebody other than the manager $[16,17]$. The results of this stage of the process include a hierarchy of tasks according to their importance, an effective daily schedule and an improvement in the quality and comfort of work. The fourth step consists of creating a daily schedule based on the analysis of the curve of working capability and human biorhythms. This stage makes practical use of the knowledge about time management. It brings about knowledge about rhythmical efficiency of employees and a development of working style. At the final stage of control, numerous techniques for checking completed tasks, results, and self-control are applied [4, 19]. Rational daily planning is based on a few rules that guarantee proper functioning of the particular time model. The basic rule is the ability to structuralise, which is subjected to specific reservations or time limits and the ability to establish goals. Task structuralisation consists of ordering the tasks according to their urgency and importance. Task prioritisation may be based on selected methods of management. One of the tools used for ordering the tasks according to their importance is the Eisenhower matrix. The matrix makes it possible to create a hierarchy of tasks according to their urgency and importance [20].

\section{AIM OF THE STUDY}

The study was aimed at demonstrating the importance of the manager's time management and presenting the effects of time management on the example of a nurse manager's work.

\section{MATERIAL AND METHODS}

The research applied the method of an individual case study and an interview technique. The authors made use of their own questionnaire consisting of questions about socio-demographic data, employ- 
ment history, and opinions about time management as well as a standardised Time Consumers questionnaire, which includes the factors responsible for distracting employees from their work. Group A consists of factors originating in professional environment, whereas group $B$ consists of the factors specific to the examined person [2].

Another questionnaire applied in the study was titled 'Self-assessment of the use of working time - identifying time thieves', and it was used to determine the respondents' opinions about time management. The examined person had to indicate on a four-degree scale how often a particular situation disturbed their daily routine. The scale ranged from 0 (the factor is always present) to 4 (the phenomenon does not occur at all) [2].

Afterwards a SWOT analysis was applied. There are four analytical categories in the matrix: strengths, weaknesses, opportunities, and threats. Strengths, also known as advantages or assets, are positive factors and resources that are responsible for the strength and success of a given person or organisation because of, for example, their ability to adapt to changing conditions. Weaknesses include factors that have a negative impact on the functioning of a given individual or organisation and lead to a decrease in the quality of services provided by them. Weaknesses impair efficiency and result in a higher number of mistakes. Opportunities, in turn, are positive elements in the environment, which can be exploited by individuals or organisations to their own advantage. It should be pointed out that the basic difference between a strength and an opportunity is the fact that people have no influence on opportunities, they cannot generate or modify them as they wish, because opportunities just appear unexpectedly regardless of any decisions made by, for example, managers. Finally, threats are situations that, because of their destructive character, can cause damage to a company or individual. As opposed to opportunities, threats are always negative. They have their origin in the external environment and remain beyond individual or managerial control [21].

The study was conducted in one of the hospitals of Małopolska region in 2018 after having been given approval by the hospital authorities. The consent of the ward nurse was obtained as well. The respondent was informed about the purpose of the study, and full anonymity was assured.

\section{CASE DESCRIPTION}

The subject of the study was a 44-year-old woman. She worked as a ward nurse in the Anaesthesiology and Intensive Care Unit in one of the hospitals in Małopolska region. The respondent lived in the countryside, was married, and had two children.
In 2017 she graduated from university with an MA degree in nursing. The respondent completed a qualifying course in Anaesthesiological and Intensive Care Nursing, Cardiopulmonary Resuscitation course and a course in Medical Interview and Physical Examination for Nurses. Moreover, she participated in specialisation trainings in Anaesthesiology and Intensive Care. The examined nurse manager did not complete post-graduate studies in health care management.

The nurse manager's period of employment was 15 years. She worked in the Anaesthesiology and Intensive Care units in two hospitals in Krakow. For two years now the respondent has been working as a ward nurse in one of the district hospitals in the Małopolska region. She is in charge of 30 nurses and 10 paramedics.

\section{RESULTS}

According to the nurse manager, the tasks that took up most of her time during her shift included controlling how the tasks were carried out by the staff, managing the team, and making sure that planned nursing treatment was provided on time. Despite some obstacles, the respondent's scores on the four-point scale showed that she was quite satisfied with her time management. The nurse applied tools improving her time management in the form of an organiser, which was an important element in the process of planning every working day. However, working in an intensive care unit is characterised by high unpredictability, which entails numerous changes in organisation of work and makes it impossible to make one clear-cut plan. In spite of difficulties, the respondent claimed that sometimes she tried to summarise her working day taking into account an analysis of performed tasks and their efficiency. An element that she never planned was a relaxing break.

The examined nurse manager declared that she had observed some changes in time management over the years. In her opinion, the changes were mostly negative ones and they had a negative impact on her effective time management. The phenomena that she mentioned included overburdening by administrative-office work connected with filling in numerous ward documents or providing nursing treatment with understaffing problems. The nurse manager believed that the observed changes were connected with the need to improve planning and pursue goals, and to achieve the goals more efficiently by delegating tasks. The respondent admitted to doing overtime or taking home part of her administrative work (preparing work schedules for the staff) in order to keep up with her duties. She put it down to missed deadlines, temporary stoppages, and the character of work in the intensive care ward. 
The respondent gave a few examples of factors that can be 'time consumers'. The first of them was too much paperwork, another one - unexpected visitors, then distractions, poor communication, rushing, and impatience. More detailed data are presented in Table 1.

\section{Self-assessment of the use of working time}

An analysis of the collected data showed that the examined ward nurse made rational use of her working time, scoring 66 points on the scale. The respondent pointed out six frequent situations that impaired the optimal use of working time. The most distracting factor was unexpected visitors, and the least distracting one was the phone repeatedly ringing (Figure 1).

\section{SWOT analysis}

The examined nurse manager carried out the SWAT analysis of her time management. She made a list of her opportunities and threats as well as strengths and weaknesses. The respondent's strengths included communication skills, openness, and competence. On the other hand, her weaknesses were, for example, lack of assertiveness in some situations or lack of knowledge about health protection management (Table 2).

The respondent indicated her strengths and weaknesses. The analysis of the findings showed that the strengths outnumbered the weaknesses. Moreover, the strengths were defined as very strong, whereas the weaknesses were not assessed as such. It may mean that the respondent concentrated more

Table 1. 'Time consumers' pointed out by the nurse manager, their causes, and preventive measures

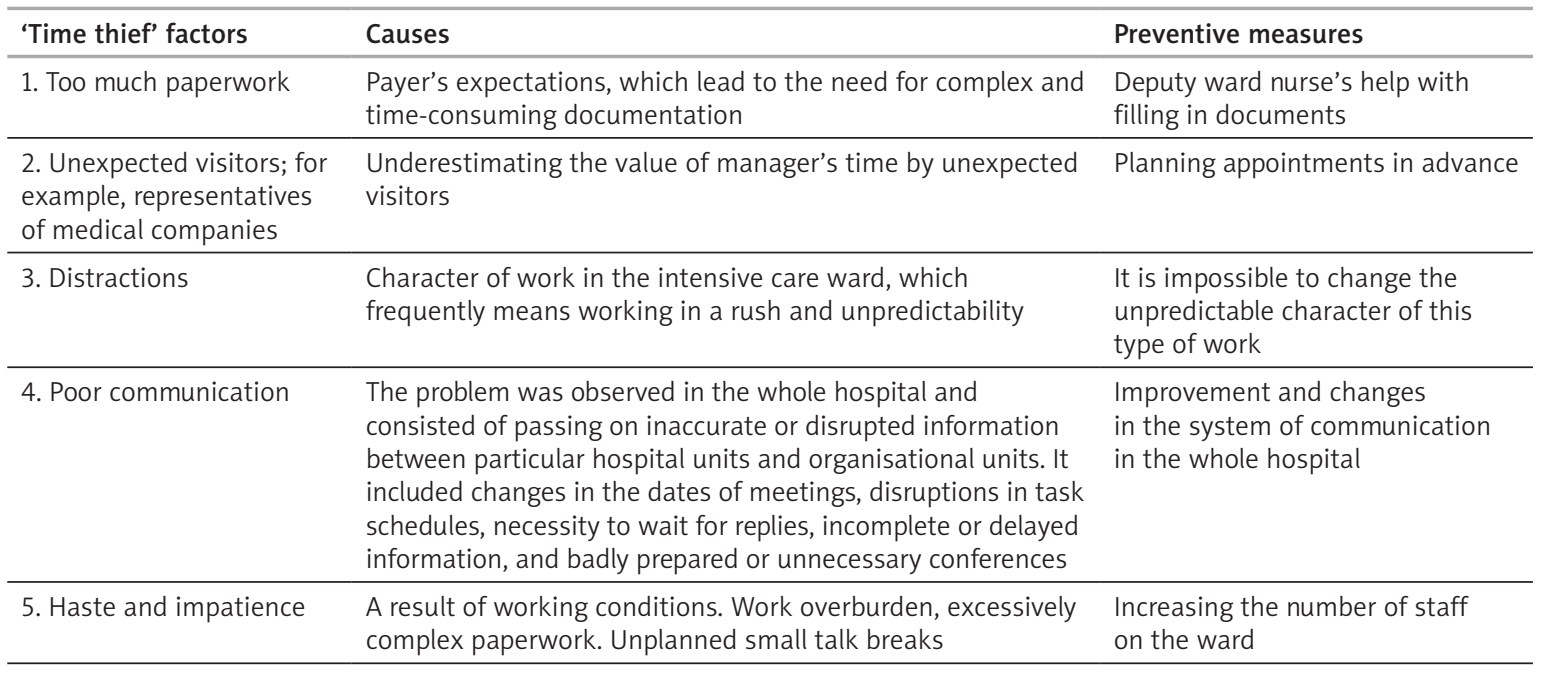

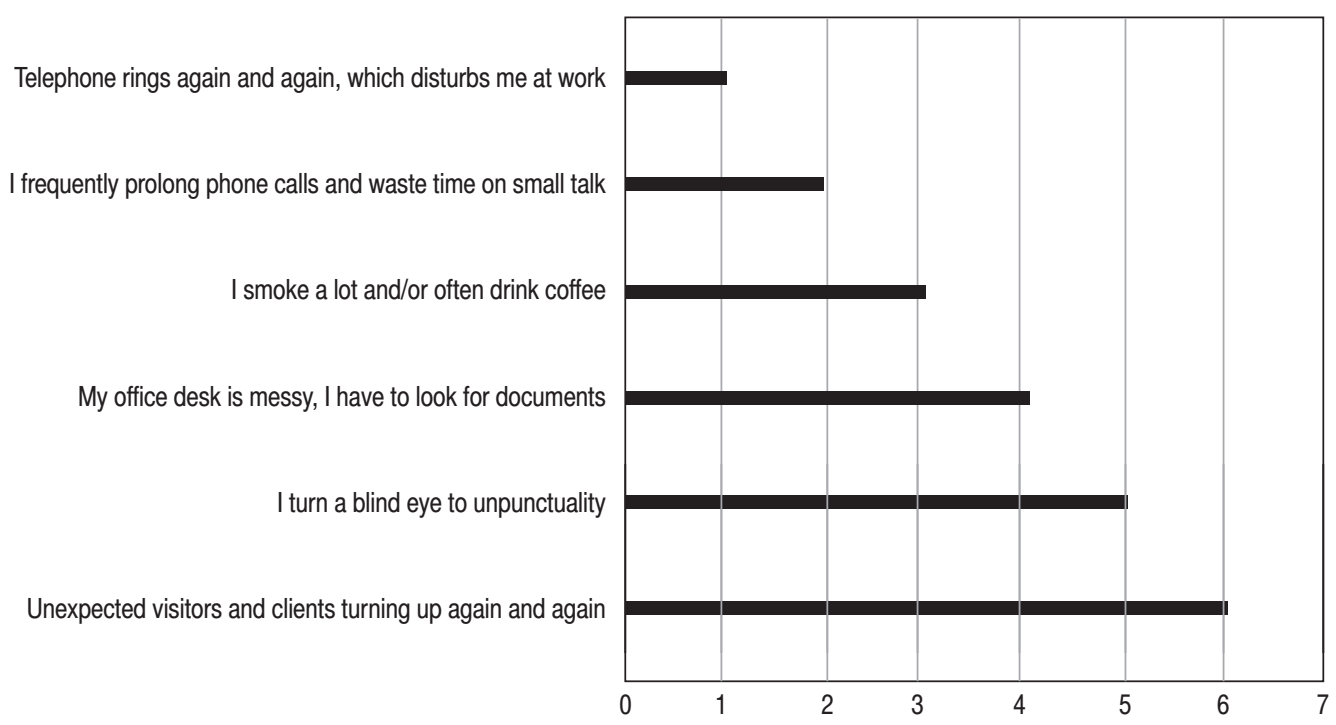

Figure 1. Self-assessment of the use of working time carried out by the ward nurse - frequent situations during a typical day at work 
on expanding her resources and did not focus too much on her disadvantages which she assessed as weak. It resulted in the domination of strengths over weaknesses not only in the quantity but also in the intensity of their incidence (Table 3).

An analysis of the results showed that the respondent observed more threats brought about by the environment than opportunities. As an opportunity, but not a very significant one, she gave an example of cooperation between the hospital and university. On the other hand, the respondent was anxious about

Table 2. Ward nurse's assessment of her strengths and weaknesses as well as opportunities and threats

\begin{tabular}{ll}
\hline Opportunities & Threats \\
\hline $\begin{array}{l}\text { The hospital belongs } \\
\text { to the university network } \\
\text { of training hospitals }\end{array}$ & $\begin{array}{l}\text { Too many responsibilities, } \\
\text { expansion of the ward } \\
\text { (unwelcome organisational } \\
\text { changes in the hospital) } \\
\text { Understaffing in nursing } \\
\text { personnel in the ward }\end{array}$ \\
\hline Strengths & Weaknesses \\
\hline Communication skills & $\begin{array}{l}\text { Lack of assertiveness } \\
\text { in some situations } \\
\text { Competence }\end{array}$ \\
Discipline & Lack of knowledge \\
& about health protection \\
\end{tabular}

Table 3. Assessment of ward nurse's strengths and weaknesses - SWOT analysis

\begin{tabular}{|c|c|c|c|c|}
\hline \multirow[t]{3}{*}{ Strengths and weaknesses } & \multicolumn{4}{|c|}{ Classifying the factor as: } \\
\hline & \multicolumn{2}{|c|}{ weakness } & \multicolumn{2}{|c|}{ strength } \\
\hline & -2 & -1 & +1 & +2 \\
\hline $\begin{array}{l}\text { Professional competence } \\
\text { and experience }\end{array}$ & & & \multicolumn{2}{|c|}{+2} \\
\hline Openness & & & \multicolumn{2}{|c|}{+2} \\
\hline Discipline & & & \multicolumn{2}{|c|}{+2} \\
\hline Lack of assertiveness & \multicolumn{2}{|c|}{-1} & & \\
\hline $\begin{array}{l}\text { Lack of thorough knowledge } \\
\text { management }\end{array}$ & \multicolumn{2}{|c|}{-1} & & \\
\hline
\end{tabular}

introducing unwelcome organisational changes because she classified this factor as a serious threat (-2 points) (Table 4).

On the basis of aforementioned strengths and weaknesses, in the third part of the analysis it was possible to determine the final management strategy. The focus of the study was to determine detailed correlations between strengths/weaknesses and opportunities/threats. An interpretation of the results of SWOT analysis showed that the examined nurse saw the possibility to make use of her strengths and to seize opportunities. According to the nurse manager, her weaknesses were significant enough to outweigh the threats (Table 5).

\section{DISCUSSION}

The source literature does not offer much information on the research into time management in medical and nursing practice in Polish hospitals and does not spread experience from international studies either. The study findings available in the source literature come from the USA, Great Britain, Denmark, and the Netherlands. These studies dealt mainly with time management in health facilities such as doctors' surgeries in basic health care centres or hospitals:

Table 4. Nurse manager's assessment of the influence of environmental factors on opportunities/threats - SWAT analysis

\begin{tabular}{|c|c|c|c|c|c|}
\hline \multirow[t]{2}{*}{ Opportunity or threat } & \multicolumn{5}{|c|}{$\begin{array}{l}\text { Assessment of the influence } \\
\text { of environmental factors }\end{array}$} \\
\hline & -2 & -1 & 0 & 1 & 2 \\
\hline $\begin{array}{l}\text { The hospital belongs to } \\
\text { the university network of } \\
\text { training hospitals }\end{array}$ & & & +1 & & \\
\hline $\begin{array}{l}\text { Organisational changes in } \\
\text { the hospital, expansion of } \\
\text { intensive care ward, too } \\
\text { many responsibilities }\end{array}$ & & & -2 & & \\
\hline $\begin{array}{l}\text { Understaffing in nursing } \\
\text { personnel on the ward }\end{array}$ & & & -2 & & \\
\hline
\end{tabular}

Table 5. Correlation between strengths/weaknesses and opportunities/threats - SWOT analysis

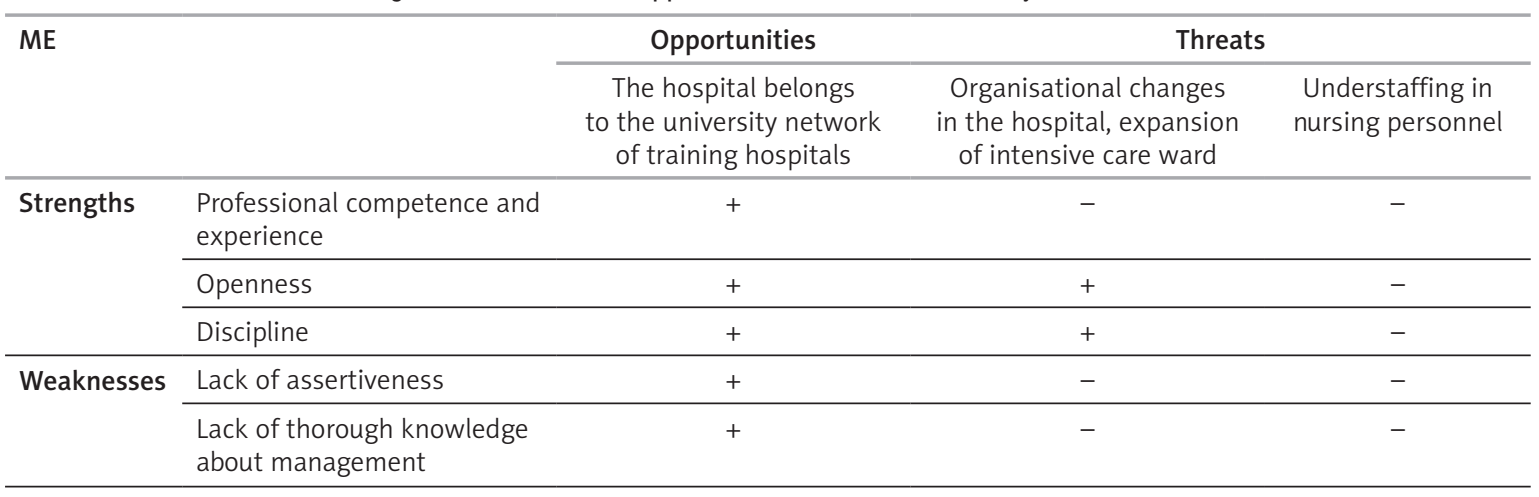


operating theatres or emergency departments [3]. The search for efficient strategies of improving the effectiveness of working time in the sector of basic health care as well as in hospital and specialist treatment have been carried out for years in the health care systems of the European Union countries. For the last dozen years Polish health care facilities have been applying modern methods of management such as outsourcing, benchmarking, reengineering, or TBM [22]. The study findings indicate an increase in the importance of knowledge and skills within organisational techniques on managerial positions in health care facilities. Managerial staff, including doctors and nurses, still demonstrate limited knowledge about working time management and lack knowledge in implementing modern solutions applied in highly developed countries [23]. It is confirmed by the study into managerial competences carried out by Kęsy in a group of doctors and nurses employed on managerial positions in 23 health facilities situated in 10 Polish voivodeships. In this study the author did not examine the time management competences but the competences of managing the time of waiting for medical services [24]. In the majority of countries, especially the ones that are just implementing free market solutions into their health care system, the main problem is the lack of adequate TBM training programs for would-be health care workers, particularly for medical professionals both at university and at work [23].

In the 1960s and 1970s in many European countries and in the USA numerous studies were carried out into time management in managerial positions of big concerns. Drucker was one of the first authors who in the mid 1960s pointed out that time management is an essential factor of the manager's efficiency. He emphasised the importance of solutions such as writing down the goals and their deadlines, eliminating useless activities, ensuring peaceful work without unnecessary breaks caused by other people, and the essence of delegating [25]. Kieżun, making comments on Mintzinberg's research, noticed that a typical manager of the $20^{\text {th }}$ century usually does not work in a systematic and reflective way. Typical managers work intensively in an irregular, pounding rhythm, dealing with a series of short tasks and making spontaneous decisions. Managers organise their work on the basis of temporary actions rather than a specified plan [26]. Observation studies carried out by Mintzinberg and Ellwood in 2005 in a group of managers showed that typical managers still work too much, on average 50 hours a week, but they do not devote much time to the main aspects of their work. A quarter of their working time is devoted to administrative activities such as keeping records, dealing with clients' complaints, technical problems, breaks, absences, mistakes of other people, or un- necessary meetings. They spend only $58 \%$ of their working time engaging in activities connected with their managerial position such as planning, organising, motivating, and controlling [27]. The authors of this study reached similar conclusions - the examined ward nurse also claimed that she spent a significant amount of time solving technical problems, dealing with other people's mistakes, and taking part in unnecessary or lengthy conferences. Additionally, the respondent did overtime or took her work home in order to catch up on her work, especially on administrative duties. Also, the examined manager did not plan her breaks and worked nursing shifts in the case of understaffing.

The source literature shows numerous flaws in the organisation of the working time of Polish managers, in which the following problems were pointed out: an increased number of working hours (9-15), low level of planning, too many duties (disintegrated work structure), processing unnecessary information, lack of work delegating skills, as well as controlling activities, which took up as much as $40 \%$ of the working time [28]. Polish studies show that managers frequently give in to the pressure of their employees, and their excessive availability leads to dysfunction in the process of time management. Therefore, the managers have too little time for contact with their employees (15\%), concept work (5-14\%), or self-study (2-4\%). On the other hand, when creating a model of the manager's work, the aspects that must be taken into consideration include the characteristics on an organisation and opportunities to improve efficiency of work, which depend on the managers themselves. Hence, the structure of time should allow for the performance of technical, administrative, and social managerial duties. According to Kieżun, optimal division of these duties should follow a 5:3:2 pattern, respectively $[29,30]$. Dysfunctions in time management might originate in the accumulation of one function or activity, which is followed by other actions leading to haste, and hence mistakes. The findings of the studies conducted by Ellwood offer the practical advice that it is better to devote more attention to the type and way in which particular activities are performed than to save time [27]. Taking into consideration numerous time consumers, including lack of goals or self-discipline, useless meetings and conversations, as well as procrastinating, the findings obtained both in this study and by other authors seem interesting enough to be the basis for further research into managerial and executive positions in Polish health care facilities.

\section{Limitations and practical implications}

The authors' own study has its own limitations because of its qualitative character and the fact that 
only one case is described, so no statistical conclusions can be drawn. Therefore, the need for further quantitative research into the issue of time management of health facility managers seems to be justified. There is a practical problem of the deficit of knowledge and skills concerning time management among managers of Polish health facilities. That is why the reflections of the examined nurse on managing her working time have an important educational and informative value.

\section{CONCLUSIONS}

On the basis of available publications and studies, the following conclusions can be drawn:

1. Time management is an essential element of the nurse manager's work because it allows for effective organisation of work, which is a rudiment of all effective and efficient actions.

2. Consistency in time management is followed by an improvement in understanding, mastering, and controlling one's tasks. It reduces the level of stress and haste and has a positive influence on an employee's outlook on life.

\section{Disclosure}

The authors declare no conflict of interest.

\section{References}

1. Kozioł L. Zarządzanie czasem pracy. Wydawnictwo Antykwa, Kraków 2000.

2. Rogusznik M. Zarządzanie czasem pracy menadżera. Dom Wydawniczy Elipsa, Warszawa 2010; 49-50.

3. Kobza J. Syrkiewicz-Świtała M. Zarządzanie czasem w systemie opieki zdrowotnej - wybrane aspekty. Med $\operatorname{Pr} 2014 ; 65$ : 555-566.

4. Seiwert LJ. Zarządzanie czasem. Agencja Wydawnicza Placet, Warszawa 2001.

5. Drucker PF. Myśli przewodnie Druckera. MT Biznes, Warszawa 2000.

6. Forsyth P. Efektywne zarządzanie czasem. HELION, Gliwice 2003; 10-11, 18-19.

7. Saganowska M. Oddziaływanie rytmów biologicznych na sprawność psychofizyczną. Problemy Nauk Stosowanych 2014; 2: 17-184.

8. Zawilska B, Żytkowski A, Woldan-Tambor A, et al. Okołodobowy typ aktywności (chronotyp), a pora i długość u młodzieży i osób dorosłych. Sen 2008; 2: 61-66.

9. Touitou Y, Haus E. Biologic rhythms in clinical and laboratory medicine. Springer-Verlag, Berlin 2012; 450-460.

10. Marciniak A, Grześk G, Koziński M, et al. Zmienność dobowa w układzie homeostazy. Folia Cardiologica 2010; 5: 1-7.

11. Kiełbasa $Ł$, Szatkowski B, Wejman M. Wpływ zmianowego systemu pracy na zdrowie i bezpieczeństwo pracownika - zagrożenie czy normalne zjawisko? Zeszyty Naukowe Politechniki Poznańskiej, Poznań 2017; 99-116.

12. Wiszniewska M, Walusiak J, Wittczak T, et al. Zespół przewlekłego zmęczenia i jego znaczenie w medycynie pracy. Med Pr 2005; 56: 387-394.
13. Makowiec-Dąbrowska T, Koszada-Włodarczyk W. Przydatność Kwestionariusza cis20R do badania zmęczenia przewlekłego. Med Pr 2006; 57: 335-345.

14. Clegg B. Błyskawiczne zarządzanie czasem. Wydawnictwo ICF Press, Kraków 2000.

15. Steward R. A model for understanding managerial job and behavior. Acad Manag Rev 1982; 1: 7-13.

16. Mioduszewski J (ed.). Metody organizacji i zarządzania. Wydawnictwo EXPOL, Uniwersytet Warmińsko-Mazurski, Olsztyn 2013.

17. Kozioł L, Pyrek R. Model systemu zarządzania czasem pracy w przedsiębiorstwie. Zeszyty Naukowe Małopolskiej Wyższej Szkoły Ekonomicznej, Tarnów 2009; 339-350.

18. Rączka K. Elastyczny czas pracy. Praca i Zabezpieczenie Społeczne 2013; 7: 2-5.

19. Kardas J. Zarządzanie w przedsiębiorstwie. Wydawnictwo Diffin, Warszawa 2008.

20. Michalski E. Zarządzanie przedsiębiorstwem. Podręcznik akademicki. Wydawnictwo Naukowe PWN, Warszawa 2013; 65.

21. Nowicki M. SWOT. In: Szumańska K (ed.). Kompendium metod i technik zarządzania. Techniki i ćwiczenia. Wydawnictwo GAB, Warszawa 2016.

22. Martyniak Z (ed.). Nowe metody i koncepcje zarządzania. Wydawnictwo Akademii Ekonomicznej, Kraków 2002.

23. Kisa A, Ersoy K. The need for time management training is universal: Evidence from Turkey. Hosp Top 2005; 83: 13-19.

24. Kęsy M. Kształtowanie kompetencji menedżerskich personelu medycznego w szpitalach. Wydawnictwo Uniwersytetu Jagiellońskiego, Kraków 2013.

25. Druker PF. The effective executive. The Definitive Guide To Getting The Right Things Done. New York, Harper Collins Publishers 2006; 25-51.

26. Kieżun W. Sprawne zarządzanie organizacją. Szkoła Główna Handlowa, Warszawa 1997.

27. Urlych W. Dysfunkcje w zarządzaniu czasem w procesie pracy kierowników. Acta Universitatios Lodziensis. Folia Oeconomica 2013; 288: 163-172.

28. Osmelak J. Organizacja pracy własnej menadżera. In: Sajkiewicz A (ed.). Kompetencje menadżerów w organizacji uczącej się. Wydawnictwo Difin, Warszawa 2008.

29. Kieżun W. Organizacja pracy własnej dyrektora. Wydawnictwo PWE, Warszawa 1974; 196-202.

30. Bieniok H. Zrządzanie czasem. Poradnik dla mało efektywnych. Wydawnictwo Difin, Warszawa 2010; 72-73. 